\title{
The Effect of Menstrual Cycle Phase on the Prognostic Factors in Patients with Premenopausal Breast Tumors
}

\author{
Berrin Papila Kundaktepe', Sinem Durmus², Cigdem Papila ${ }^{3}$, Mehmet Velidedeoglu', Remise Gelisgen², Hafize Uzun² \\ 'Department of General Surgery, Cerrahpasa Medical Faculty, Istanbul University-Cerrahpasa, Istanbul, Turkey \\ ${ }^{2}$ Department of Medical Biochemistry, Cerrahpasa Medical Faculty, Istanbul University-Cerrahpasa, Istanbul, Turkey \\ ${ }^{3}$ Department of Internal Medicine, Division of Oncology, Cerrahpasa Medical Faculty, Istanbul University-Cerrahpasa, Istanbul, Turkey
}

*Corresponding author:

Professor Hafize Uzun, MD

Department of Medical Biochemistry,

Cerrahpasa Faculty of Medicine,

Istanbul University-Cerrahpasa

34303, Cerrahpasa-Istanbul, Turkey

E-mail: huzun59@hotmail.com

\section{Rezumat \\ Efectul fazelor ciclului menstrual asupra factorilor de prognostic pentru cancerul de sân diagnosticat în perioada de premenopauză}

Context:Receptorii de estrogen şi de progesteron pozitivi şi nivelul de expresie a genei c-erbB2 sunt factori importanți în determinarea evoluției şi agresivități cancerului mamar. Deți importanța factorilor hormonali în proliferarea, migrarea şi diferențierea celulelor tumorale este din ce în ce mai evidentă, este nevoie de mai multe dovezi care să susțină această teorie. Efectul momentului efectuării intervenției chirurgicale pentru cancerul se sân în timpul ciclului menstrual asupra prognosticului rămâne controversat. Pentru a clarifica această ipoteză, ne-am propus să determinăm importanța ajustării momentului operației în funcție de ciclul menstrual, examinând relația dintre receptorul de estrogen, receptorul de progesteron, gena c-erbB2 şi faza ciclului menstrual la pacientele cu cancer de sân apărut în perioada de premenopauză. Metodă:Studiul nostru a fost conceput retrospectiv şi a inclus 50 de paciente în premenopauză la care s-a intervenit chirurgical pentru cancer mamar.

Rezultate: Rezultatele studiului au arătat că pacientele aflate în faza luteală au avut un număr mai mare de receptori de estrogen şi de progesteron, gena c-erbB2 mai slab exprimată şi un număr mai mic de metastaze ganlionare axilare în comparație cu pacientele operate în timpul fazei foliculare.

Concluzie: efectuarea intervenției chirurgicale pentru cancerul de sân în timpul fazei luteale la femeile în premenopauză asociază un prognostic mai bun. Deți sunt necesare studii la scară mai mare, studiul de față indică faptul că se pot obține rezultate mai bune prin efectuarea unei interventiii chirurgicale în faza luteală la pacientele cu cancer de sân în perioada premenopauzei. 
Cuvinte cheie: cancer de sân, ciclu menstrual, premenopauză, receptori, progesteron, receptori, estrogen

\begin{abstract}
Background: Estrogen receptor and progesterone receptor positivity and c-erbB2 gene expression levels are important in determining breast cancer development and aggression. Although the importance of hormonal factors in tumor cell proliferation, migration and differentiation is increasing, it needs more evidence. The effect of $\mathrm{BC}$ surgery timing during the menstrual cycle on prognosis remains controversial. In order to clarify this hypothesis, we aimed to determine the importance of adjusting the timing of surgery according to the menstrual cycle by examining the relationship between estrogen receptor, progesterone receptor, c-erbB2 gene and the menstrual cycle phase in patients with premenopausal breast cancer.

Method:Our study was designed retrospectively. 50 patients with premenopausal breast cancer who were operated were included in the study.

Results: Our results showed that the patients in the luteal phase had higher ER positivity, PR positivity and c-erbB2 negativity, and the number of metastatic axillary lymph nodes was lower than the patients in follicular phase.

Conclusion: BC surgery during the luteal phase in pre-menopausal women is associated with a better clinical outcome. Although larger-scale studies are needed, our results suggest that better results can be achieved by performing surgery in luteal phase in $\mathrm{BC}$ patients during premenopausal period.
\end{abstract}

Key words: breast cancer, menstrual cycle, premenopause, receptors, progesterone, receptors, estrogen

\section{Introduction}

Breast cancer $(\mathrm{BC})$ is the most common malignancy and the leading cause of cancer related death among women all around the world (1). Although developed countries report higher rates of $\mathrm{BC}$ incidence and mortality, changes in the incidence of $\mathrm{BC}$ are most dramatic in low-middle income countries including Turkey (2). The World Health Organization categorized countries into four categories: basic, limited, developed and maximum. Turkey is a middleincome country between limited and enhanced level regarding their sources $(3,4)$. Age and induced abortion were found to be significantly associated with increased $\mathrm{BC}$ risk whereas oral contraceptive use was observed to be associated with decreased $\mathrm{BC}$ risk among Turkish women in Istanbul (2).
$\mathrm{BC}$ care is complex and requires a multidisciplinary approach. There is mounting evidence that the timing of surgery within the menstrual cycle has a significant effect on prognosis in premenopausal women with breast carcinoma (5-12). For the first time in 1991, the effect of the timing of surgery in patients with both estrogen receptor (ER) positive and negative tumors was demonstrated by Badwe et al. (5). Timing of operation in relation to menstrual phase might affect outlook in premenopausal women with operable breast cancer.

We aimed to investigate the importance of the menstrual cycle in adjusting the timing of surgery in patients with premenopausal breast cancer by examining the relationship between prognostic factors and the menstrual cycle in the light of the data in the literature. 


\section{Methods}

\section{Study Design and Participants}

This retrospective study was conducted in Cerrahpasa Medical Faculty in period from March to October 2019. The study included 50 patients with $\mathrm{BC}$ who were followed up in the Department of Oncology, Cerrahpasa Medical Faculty, and Istanbul University-Cerrahpasa. All individuals included in the study were randomly selected from premenopausal breast cancer patients.

Inclusion criteria in the study;

- All patients not receiving neoadjuvant chemotherapy before surgery.

- Modified radical mastectomy + axillary dissection (surgical intervention for therapeutic purposes) was performed on patients diagnosed (Partial mastectectomy + axillary dissection for T1N1M0 tumors; Modified radical mastectomy + axillary dissection for T2N1M0) with breast cancer that had regular menstruation and had radiological axillary involvement. Sentinel lymph node biopsy was performed in all patients during the operation. An axillary dissection was applied to those who had positive biopsy results.

- After surgery, the files of these patients were retrospectively analyzed. The data (pathology, menstrual cycle phase) were obtained from the data in the file.

Clinical findings, menstrual cycle phase, number of axillary lymph nodes, estrogen receptor and c-erbB-2 gene expression results, treatment and clinical course of the patients were retrospectively obtained from the polyclinic file of the patients. Postmenopausal breast cancer patients were not included in the study. Last menstrual period was also categorized according to the menstrual cycle phase definitions of Badwe et al (1991) (luteal: days 0-2 and 13-32; follicular: days 3-12) (5).

Pathology investigations include evaluation of primary tumor and lymph nodes. ER, PR and HER-2/neu status were evaluated by immunohistochemistry (IHC) and silver in situ hybridization (SISH). ER, PR and HER-2/ neu status were documented in the patient files.

\section{Statistical Analysis}

In this study, SPSS 21.0 software was used. Continuous variables were tested for normal distribution by the Shapiro-Wilk test. Results for normally distributed continuous variables are expressed as means \pm standard deviations; categorical variables are expressed as numbers (percentages). Student's t test was used to compare mean values.Chi-Square test were used to compare frequencies and percentages between the groups. A p value equal to or lower than 0.05 was considered statistically significant.

\section{Results}

Table 1 displays baseline characteristics for

Table 1. Baseline characteristics for patients

\begin{tabular}{|c|c|c|c|}
\hline & $\begin{array}{l}\text { Luteal phase } \\
(n=23)\end{array}$ & $\begin{array}{l}\text { Folicular phase } \\
(n=27)\end{array}$ & p \\
\hline Age & $40.00 \pm 5.52$ & $40.44 \pm 5.14$ & $0.770^{t}$ \\
\hline Metastatic axillary lymph nodes & $1.30 \pm 2.46$ & $3.37 \pm 3.62$ & $<0.001^{t}$ \\
\hline $\begin{array}{l}\text { Breast cancer location } \\
\text { Left } \\
\text { Right }\end{array}$ & $\begin{array}{l}8(\% 34.78) \\
15(\% 65.22)\end{array}$ & $\begin{array}{l}12(\% 44.44) \\
15(\% 55.56)\end{array}$ & $0.343^{c}$ \\
\hline $\begin{array}{l}\text { ER status } \\
\quad \text { ER-/ER }+/ E R++/ E R+++\end{array}$ & $0(\% 0) / 11(\% 48) / 3(\% 13) / 9(\% 39)$ & $11(\% 41) / 12(\% 44) / 4(\% 15) / 0(\% 0)$ & $<0.001^{c}$ \\
\hline $\begin{array}{l}\text { PR status } \\
\quad \text { PR-/PR }+/ P R++/ P R+++\end{array}$ & $4(\% 17) / 6(\% 26) / 6(\% 26) / 7(\% 30)$ & $15(\% 56) / 10(\% 37) / 2(\% 7) / 0(\% 0)$ & $<0.001^{\mathrm{c}}$ \\
\hline $\begin{array}{l}\text { c-erbB-2 status } \\
\text { cERB-/cERB }+/ c E R B++/ c E R B+++\end{array}$ & $20(\% 87) / 3(\% 13) / 0(\% 0) / 0(\% 0)$ & $12(\% 44) / 3(\% 11) / 1(\% 4) / 11(\% 41)$ & $<0.001^{c}$ \\
\hline
\end{tabular}


patients with premenopausal breast cancer. At the time of the surgical procedure, 23 women (46\%) were classified as luteal phase; and 27 women (54\%) were classified as follicular phase. No significant difference was found between the mean age of the patients in the luteal phase and follicular phase. The number of metastatic axillary lymph nodes in the luteal phase was significantly lower in women with breast cancer than in the follicular phase. There was no significant difference between patients in the luteal phase and the follicular phase in terms of tumor localization. ER positivity, PR positivity and c-erb B2 negativity were higher in the luteal phase than follicular phase.

\section{Discussion}

The findings from both qualitative and quantitative analysis of studies on performing BC surgery in a certain phase of the menstrual cycle are unclear. In the good phase of the menstrual cycle (Days $0-2$ and 13-32), women with ER (+) tumors have a significantly better outcome than those with ER (-) tumors and follicular phase surgery is associated with a poor prognosis regardless of hormone status (11). A specific breast phenotype with lack of ER, PR, and c-erbB-2 expression, the so-called "triple-negative" phenotype, is linked with poor prognosis (13).

The development and clinical course of BC is modulated by various endocrine effects. It is now widely recognized that endocrine interventions represent the most effective approaches for reducing the risk of recurrence and death for hormone-responsive primary breast cancer and reducing patients at risk of developing this disease. In the last 30 years, some hypotheses have been established on the basis of the endocrine-cancer relationship, and although many have been proven, there are still hypotheses awaiting clarification.

There is still discordance between studies and well-conducted prospective studies have provided evidence, both for and against, rescheduling surgery to the luteal phase (14). One of these hypotheses was proposed by
Hrushesky et al. (15) in 1989 and they suggested the concept of surgical intervention to treat $\mathrm{BC}$ in premenopausal women according to the stage of the menstrual cycle. The authors suggested that premenopausal patients with $\mathrm{BC}$ who were operated during the perimenstrual period of the menstrual cycle had higher disease-free and overall survival rates compared to patients operated in other phases of the cycle (5). However, according to the results of the retrospective, prospective and meta-analysis studies performed on this hypothesis for the last three decades; while some studies $(5,16)$ support Hrushesky et al. (15), there are studies reporting that the menstrual cycle does not affect the outcome $(17,18)$, or that the opposite results (patients who underwent surgical treatment in the follicular phase are better than those receiving luteal phase surgery) (19).

Continuous fluctuations of estrogen and progesterone throughout the reproductive period in women affect the phenotype and function of breast, stromal and immune cells including macrophages and regulatory $\mathrm{T}$ cells, as well as the turnover of the mammary epithelium, stem cells, and extracellular matrix. Collectively, these events can lead to genome instability, increase the likelihood of random genetic mutations, reduce immune supervision and increase tolerance in the mammary gland; thus, increasing the risk of breast cancer onset (20). In addition, fluctuations in estrogen and progesterone throughout the menstrual cycle direct the proliferation, differentiation and apoptosis in the mammary gland epithelium (21). Menstrual cycle phases in women; Pituitary gland hormones, follicle stimulating hormone and luteinizing hormone and ovarian hormones are regulated by fluctuations in estrogen and progesterone. Estrogen exerts proliferative effects on mammary epithelial channels by direct ERs, as well as up-regulates the expression of PR during the luteal phase of the cycle (20). ER, PR and c-ERBB2 (HER-2/neu) are important therapeutic and prognostic markers for breast carcinoma (22). Vasei et al. (23) showed that the ER and PR are higher in the luteal phase. 
In another study, they reported that ER positivity was higher in the follicular phase and the PR was found to be independent of the menstrual cycle; and if the condition of the hormone receptor is found to be negative, it is necessary to reevaluate the phase of the menstrual cycle in which the operation is performed (24). Liu et al. (25) reported that surgery performed during the follicular phase provides a more favorable prognosis compared with the luteal phase.

\section{Conclusion}

It is concluded that prognostic factors are better in patients with luteal phase. Our results suggest that $\mathrm{BC}$ surgery during the luteal phase in pre-menopausal women is associated with a better clinical outcome. Although larger-scale studies are needed, our results suggest that better results can be achieved by performing surgery in luteal phase in BC patients during premenopausal period. Prospective randomized clinical trials are also necessary to determine the full extent of survival benefits of luteal surgical timing. We believe that this study will guide clinicians with a retrospective large series of patients that will be investigated in the future.

We believe that this study will guide clinicians with a retrospective large series of patients that will be investigated in the future.

\section{Funding: Not applicable}

\section{Conflict of Interest}

The authors declare that they have no competing interests.

\section{Ethic}

Approval from the Ethics Committee of Cerrahpasa Medical Faculty for this study was received, and the study was conducted in conformity with the Declaration of Helsinki. Written informed consent of all participants was obtained before starting the study (No: 22721 date: 8 February 2019).

\section{References}

1. Matsen CB, Neumayer LA. Breast cancer: a review for the general surgeon. JAMA Surg. 2013;148(10):971-9.

2. Ozmen V, Ozcinar B, Karanlik H, Cabioglu N, Tukenmez M, Disci R, et al. Breast cancer risk factors in Turkish women--a University Hospital based nested case control study. World J Surg Oncol. 2009;7:37.

3. Masood S. Assessment of prognostic factors in breast fine-needle aspirates. Am J Clin Pathol. 2000;113(5 Suppl 1):S84-96.

4. Sharif MA, Mamoon N, Arif A, Mushtaq S, Khadim MT. Histological and immuno-histochemical study of male breast carcinoma in Northern Pakistan. J Pak Med Assoc. 2009;59(2):67-71.

5. Badwe RA, Gregory WM, Chaudary MA, Richards MA, Bentley AE, Rubens RD, et al. Timing of surgery during menstrual cycle and survival of premenopausal women with operable breast cancer. Lancet. 1991;337(8752): 1261-4.

6. Fentiman IS, Gregory WM, Richards MA. Effect of menstrual cycle phase on surgical treatment of breast cancer. Lancet. 1994; 344(8919):402.

7. Veronesi U, Luini A, Mariani L, Del Vecchio M, Alvez D, Andreoli C, et al. Effect of menstrual phase on surgical treatment of breast cancer. Lancet. 1994:343(8912):1545-7.

8. Goldhirsch A, Gelber RD, Castiglione M, O'Neill A, Thürlimann B, Rudenstam C-M, et al. Menstrual cycle and timing of breast surgery in premenopausal node-positive breast cancer: results of the International Breast Cancer Study Group (IBCSG) Trial VI. Ann Oncol. 1997;8(8):751-6.

9. Senie RT, Tenser SM. The timing of breast cancer surgery during the menstrual cycle. Oncology (Williston Park). 1997:11(10):1509-17; discussion 1518-22, 1524

10. Hagen AA, Hrushesky WJ. Menstrual timing of breast cancer surgery. Am J Surg. 1998:175(3):245-61.

11. Cooper LS, Gillett CE, Patel NK, Barnes DM, Fentiman IS. Survival of premenopausal breast carcinoma patients in relation to menstrual cycle timing of surgery and estrogen receptor/progesterone receptor status of the primary tumor. Cancer. 1999; 86(10):2053-8.

12. Kucuk Al, Atalay $\mathrm{C}$. The Relationship between Surgery and Phase of the Menstrual Cycle Affects Survival in Breast Cancer. J Breast Cancer. 2012; 15(4):434-40.

13. Walsh EM, Keane MM, Wink DA, Callagy G, Glynn SA. Review of Triple Negative Breast cancer and the impact of inducible Nitric Oxide synthase on Tumor Biology and patient outcomes. Crit Rev Oncog. 2016;21(5-6):333-351.

14. Chaudhry A, Puntis ML, Gikas P, Mokbel K. Does the timing of breast cancer surgery in pre-menopausal women affect clinical outcome? An update. Int Semin Surg Oncol. 2006;3:37.

15. Hrushesky WJ, Bluming AZ, Gruber SA, Sothern RB. Menstrual influence on surgical cure of breast cancer. Lancet. 1989; 2(8669):949-52.

16. Veronesi U, Luini A, Mariani L, Del Vecchio M, Alvez D, Andreoli C, et al. Effect of menstrual phase on surgical treatment of breast cancer. Lancet. 1994:343(8912):1545-7.

17. Goldhirsch A, Gelber RD, Castiglione M, O'Neill A, Thürlimann B, Rudenstam CM, et al. Menstrual cycle and timing of breast surgery in premenopausal node-positive breast cancer: Results of the International Breast Cancer Study Group (IBCSG) Trial VI. Ann Oncol. 1997;8(8):751-6.

18. Nathan B, Bates T, Anbazhagan R, Norman AR. Timing of surgery for breast cancer in relation to the menstrual cycle and survival of premenopausal women. Br J Surg. 1993;80(1):43

19. No authors listed. Timing of surgery for breast cancer and menstrual cycle. Lancet. 1991:338(8763):391-2.

20. Atashgaran V, Wrin J, Barry SC, Dasari P, Ingman WV. Dissecting the Biology of Menstrual Cycle-Associated Breast Cancer Risk. Front Oncol. 2016;6:267.

21. Bernhardt SM, Dasari P. Walsh D, Townsend AR, Price TJ, Ingman WV. Hormonal Modulation of Breast Cancer Gene Expression: Implications for Intrinsic Subtyping in Premenopausal Women. Front Oncol. 2016;6:241.

22. Idirisinghe PKA, Thike AA, Cheok PY, Man-Kit Tse G, Chi-Wai Lui P, FookChong $\mathrm{S}$, et al. Hormone receptor and c-ERBB2 status in distant metastatic and locally recurrent breast cancer. Pathologic correlations and clinical significance. Am J Clin Pathol. 2010; 133(3):416-29.

23. Vasei M, Azarpira N, Talei A. Status of estrogen and progesterone receptors in various phases of the menstrual cycle in breast cancer. Arch Iran Med. 2006;9(3):250-3.

24. Atalay C, Kanliöz M, Altinok M. Menstrual cycle and hormone receptor status in breast cancer patients. Neoplasma. 2002; 49(4):278.

25. Liu Y, Wang Y, Zhou L, Yin K, Yin W, Lu J. Prognostic effect of menstrual cycle on timing of surgery in premenopausal breast cancer patients. Am J Surg. 2015;210(3):506-11. 